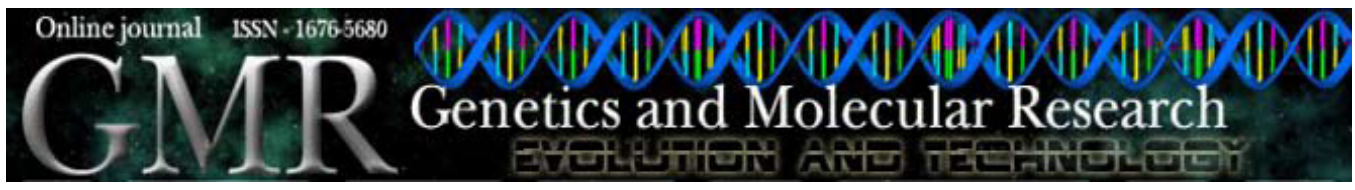

\title{
Bos indicus or Bos taurus mitochondrial DNA - comparison of productive and reproductive breeding values in a Guzerat dairy herd
}

J.C.C. Paneto ${ }^{1}$, J.B.S. Ferraz ${ }^{2}$, J.C.C. Balieiro ${ }^{2}$, J.F.F. Bittar ${ }^{1}$, M.B.D. Ferreira ${ }^{1}$, M.B. Leite' ${ }^{1}$ G.K.F. Merighe $^{2}$ and F.V. Meirelles ${ }^{2}$

${ }^{1}$ Instituto de Estudos Avançados em Veterinária, UNIUBE/FAZU/ABCZ, Uberaba, MG, Brasil

${ }^{2}$ Faculdade de Zootecnia e Engenharia de Alimentos, USP, Pirassununga, SP, Brasil

Corresponding author: J.C.C. Paneto

E-mail: paneto@yahoo.com

Genet. Mol. Res. 7 (3): 592-602 (2008)

Received April 28, 2008

Accepted June 17, 2008

Published July 1, 2008

\begin{abstract}
The observation of bovine mitochondrial DNA (mtDNA) polymorphisms allows the separation of American zebu cattle, according to its maternal lineage ancestry, into two groups: one with Bos indicus mtDNA and other with Bos taurus mtDNA. The aim of the present study was to determine the productive and reproductive differences between these two groups, in a Guzerat dairy herd. The genotyping of a sample of 56 animals allowed the categorization of most of the 3835 animals in the pedigree file. The production file included 3528 calving and 3198 lactation records from 729 cows, born during the years 1947 to 2007. The traits considered were: lactation milk yield (LMY); days in milk (DIM); age at first calving (AFC), and calving interval (CI). Heritabilities and breeding values were estimated using an animal model. The regression of the average breeding values per year of birth indicated the genetic trends of the herd. The heritability coefficients estimated for LMY, DIM, AFC, and CI were 0.42, 0.43, 0.20, and 0.10,
\end{abstract}


respectively. The genetic trends were similar for both groups, pointing to an improvement in the productive and a worsening in the reproductive traits. The two groups differed significantly regarding the average estimated breeding values for LMY, DIM and AFC, in the starting period, until 1970, but no differences were observed in the more recent years, after 1970. The segregation between the groups existed in the starting period, probably because the Bos taurus contributions to the herd had occurred more recently at that moment. The conclusion is that mtDNA has no significant effect on these traits.

Key words: Bos indicus; Bos taurus; Mitochondrial DNA; Guzerat; Production; Reproduction

\section{INTRODUCTION}

Amongst Bos indicus dairy breeds, the Guzerat and the Gyr can be considered the most important ones in Brazil, because of their abilities to produce milk under tropical conditions. Animals from both breeds are also frequently used in crossbreeding systems with Bos taurus dairy breeds, contributing to adaptability and adding heterosis to the crossbred animals (Martinez et al., 1988; Madalena et al., 1990; Valente et al., 2001). According to Santos (2005), there are about 92,000 animals in the national registered Guzerat herd, which represents about $3.5 \%$ of the animals from zebu cattle (Bos indicus) breeds in the country.

Even though, only about 6300 animals from Bos indicus breeds came from India to Brazil, the current Brazilian commercial cattle herd is the biggest in the world (Pereira, 2004). While some females were included in shipments, most imported animals were males, which were mated with "native" Bos taurus cows with ancestries in the Iberian Peninsula (Meirelles et al., 1999). The presence of Bos taurus ancestry can be verified in the maternal lineages of any animal throughout its cytoplasmic inheritance. As described in the beginning of the last century (Correns, 1909, cited by Meirelles et al., 1999), cytoplasmic inheritance is controlled mainly through the expression of genes contained within the mitochondrion, inherited almost exclusively through maternal lineage in mammals (Hutchison III et al., 1974; Giles et al., 1980). Using this approach, Meirelles et al. (1999) studied the mitochondrial DNA (mtDNA) content of cattle from three zebu breeds, confirming that a large proportion of American zebu carry Bos taurus mtDNA. These results support the hypothesis that part of today's zebu cattle maternal lineages were derived by backcrossing "native" females of Bos taurus origin with Bos indicus bulls imported from India.

The identification of polymorphisms for Bos indicus and Bos taurus mtDNA made possible the classification of the animals according to their cytoplasmic origins. This information contributed to improving the understanding of the structure of the current zebu herds. It remains unknown whether mitochondrial genotypes participate in productive and reproductive traits in zebu cattle.

The aim of the present study was to determine the productive and reproductive genetic differences between zebu cattle with Bos indicus or Bos taurus cytoplasmic origins, in a Guzerat dairy herd. 


\section{MATERIAL AND METHODS}

\section{Animals and sampling}

Data from a Guzerat dairy herd were analyzed. The pedigree information was very complete, including the registration of most animals born in the herd since the first shipments, in the beginning of the last century. The herd remained with no significant introductions of animals from other herds since then, showing historically increasing levels of inbreeding.

The complete pedigree file contained 3835 animals, and was analyzed with the use of the LINMAT software (Mourão et al., 2006), which creates a file containing parents, grandparents and great-grandparents of all animals from a given list. Here, the starting list contained all 380 animals alive in the current herd. After one run, a new list was produced, containing only the mothers of the maternal grandmothers of the animals from the starting list, i.e., the females from the third generation back in the maternal lineages. Another run, with this list, produced another new list and so on, until getting to the 12 oldest females in the file, from the shipment period. Taking into consideration these females, 56 descendants from maternal lineages were chosen for DNA sampling and mtDNA genotyping.

\section{Mitochondrial DNA analysis}

Total DNA was extracted from leukocytes by standard procedures (Sambrook et al., 2001). Amplification of mtDNA was performed using these primers: BosmtF1 5'-CCCAACGAGGAAAATATACC-3' and BosmtR1 - 5'-AACCGCAAACAACCTCTTCC-3', which were synthesized to amplify a region of the ND5 gene of the mitochondrial genome (nucleotide 11,770 to 12,525 according to Anderson et al., 1982 and Meirelles et al., 1999). The polymerase chain reaction was performed using $3.5 \mathrm{mM} \mathrm{MgCl}_{2}$ for 35 cycles of $30 \mathrm{~s}$ at $94^{\circ} \mathrm{C}, 45 \mathrm{~s}$ at $58^{\circ} \mathrm{C}$ and $45 \mathrm{~s}$ at $72^{\circ} \mathrm{C}$. Amplified mtDNA was digested with HindIII, electrophoresed on $1.5 \%$ agarose gels, stained with ethidium bromide and determined with the appropriate filter in a Fuji Fla 3000G Laser Scanner (Fuji Film Co.), using Image Gauge version 3.12 software. The presence of the HindIII restriction site within the amplified region is indicative of Bos taurus mtDNA.

From the results obtained on the sampled animals, the classification was completed for all maternal lineage ancestry, up to the oldest females in the pedigree file. All maternal lineage descendants of each female were then classified identically. As a result, $97 \%$ of the animals were classified as pertaining to Bos indicus or Bos taurus maternal lineage.

\section{Productive and reproductive data analysis}

The data file included 729 females, born during the years 1941 and 2005, containing 3528 calving and 3198 lactation records, from the years 1947 and 2007. The traits analyzed were: lactation milk yield (LMY); days in milk (DIM); age at first calving (AFC), and calving interval (CI).

The heritability coefficients of the traits and the genetic breeding values of the animals were estimated with the help of the restricted maximum likelihood method (REML), using an animal model and the software MTDFREML (Boldman et al., 1995).

The statistical model for the analysis of LMY and DIM included: the contemporary 
groups, composed by year and the season of each calving, as a fixed effect; the linear and quadratic components of age at calving and inbreeding coefficient of the cow, as covariates; the animal's additive genetic random effect, the individual permanent environment as uncorrelated random effect, and the residual random effect. In the analysis of milk yield, some authors have used comparable statistical models, but without considering the inbreeding coefficient as a covariate (Cobuci et al., 2000; Cruz et al., 2006; Peixoto et al., 2006). In the present study, since there were a great number of inbred animals in the herd, the inclusion of the inbreeding coefficient was necessary for the adjustment of the estimated breeding values of highly inbred cows or bulls with highly inbred daughters. Without the inclusion of the inbreeding coefficient in the model, these animals would have their breeding values underestimated because of inbreeding depression. Other authors also agreed with this approach, using or defending the use of the inbreeding coefficients in the model (Kennedy et al., 1988; Ferraz, 1993; Mourão et al., 2005; Powell and Norman, 2006).

The analysis of AFC considered a model that contemplated: the contemporary groups, composed by year and season of birth, as a fixed effect, the linear component of the inbreeding coefficient as a covariate; the animal additive genetic random effect, and the residual random effect. Duarte and Bastos (2005) used a similar model, differing only in regard to the inbreeding coefficient, as discussed earlier for milk yield.

The model used in the analysis of CI was similar to the one used with milk yield and days in milk, despite the fact that the inbreeding coefficient was considered only with its linear component. Duarte and Bastos (2005) also considered year and season, when analyzing the calving interval in a Guzerat herd, but they considered order of parturition instead of age at calving. All possible effects considered have been previously tested for their significance in each model used, with a general linear model procedure, using the software Statistica 7.1 (StatSoft, Inc., 2003).

\section{MtDNA Bos indicus x mtDNA Bos taurus}

All animals in the pedigree were classified, and the population was divided into two groups: Bos taurus indicus and Bos taurus taurus. The mean genetic breeding values per year of birth were calculated for each group, and for each trait. This information was used to draw one scatterplot for each trait, including both groups. The regression of the mean breeding values per year of birth indicated the genetic trends of the two groups in the herd. The means from the two groups were compared with each other using the Student $t$-test, regarding the estimated breeding values for LMY, DIM, AFC, and CI, with the use of the software Statistica 7.1 (StatSoft, Inc., 2003).

\section{RESULTS AND DISCUSSION}

\section{Mitochondrial DNA analysis}

Among the 729 females with production records in the herd, 504 (69\%) were classified as being from Bos indicus maternal lineages, 205 (28\%) from Bos taurus maternal lineages and 20 (3\%) remained undefined, because they had no descendants, from maternal lineages, alive in the herd to be analyzed. These proportions were close to those observed by Meirelles et al. (1999) in samples from animals registered as descendants of imported animals from the breeds Gyr and Nellore. In reviewing the literature, no previous publications were found regarding mtDNA analysis in Guzerat herds. 


\section{Productive and reproductive data analysis}

The phenotypic performance of the herd, including all females with records in the file, is presented in Table 1. The numbers of valid records, minimums, maximums, means, standard deviations and variation coefficients for LMY, DIM, AFC, and CI are shown.

\begin{tabular}{|c|c|c|c|c|c|c|}
\hline Trait & $\mathrm{N}$ & Min. & Max. & Mean & SD & CV (\%) \\
\hline LMY (kg) & 3198 & 840 & 4847 & 2476 & 684 & 28 \\
\hline DIM (days) & 3198 & 130 & 365 & 293 & 43 & 15 \\
\hline AFC (days) & 654 & 791 & 1887 & 1380 & 211 & 8 \\
\hline CI (days) & 2242 & 273 & 1279 & 500 & 140 & 15 \\
\hline
\end{tabular}

The phenotypic LMY and DIM performances observed in this study were close to those observed in other studies with the Guzerat breed (Cobuci et al., 2000; Martinez et al., 2000; Cruz et al., 2006).

The observed mean for age at first calving in the herd studied, 1380 days, was very close to the results from Martinez et al. (2000) and from Duarte and Bastos (2005), who found values of 1346 and 1381 days, respectively, when studying reproductive traits in the Guzerat breed.

The mean calving interval observed in this study, 500 days, was higher than the 454 and 407 days observed by Martinez et al. (2000) and Duarte and Bastos (2005), respectively. The greater age at first caving may be due to inbreeding depression and to the fact that the cited studies involved dual-purpose Guzerat herds, while the present study was conducted with a dairy Guzerat herd. Thus, the better weight gain performance may be related to earlier mating of heifers in those herds.

The phenotypic performances of both maternal lineage groups, Bos indicus and Bos taurus, are shown in Tables 2 and 3, which represent the starting period, until 1970, and the more recent period, from 1971 to 2005 , respectively.

Table 2. Phenotypic performances of the maternal lineage groups Bos indicus and Bos taurus, for animals
born until 1970.
\begin{tabular}{lccccc}
\hline Trait & $\begin{array}{c}\text { Mean } \\
\text { (Bos indicus) }\end{array}$ & $\begin{array}{c}\text { Mean } \\
\text { (Bos taurus) }\end{array}$ & $\begin{array}{c}\text { N } \\
\text { (Bos indicus) }\end{array}$ & $\begin{array}{c}\text { N } \\
\text { (Bos taurus) }\end{array}$ & P* $^{*}$ \\
\hline LMY (kg) & 2110 & 2164 & 722 & 381 & 0.2091 \\
DIM (days) & 288 & 293 & 722 & 381 & 0.0634 \\
AFC (days) & 1276 & 1336 & 107 & 54 & 0.0229 \\
CI (days) & 481 & 473 & 577 & 295 & 0.3545 \\
\hline
\end{tabular}

$\mathrm{N}=$ number of valid records; $\mathrm{LMY}=$ lactation milk yield; DIM = days in milk; AFC = age at first calving; $\mathrm{CI}=$ calving interval. $*$ The differences between groups were considered to be significant if $\mathrm{P}<0.05$. 


\begin{tabular}{|c|c|c|c|c|c|}
\hline Trait & $\begin{array}{c}\text { Mean } \\
(\text { Bos indicus })\end{array}$ & $\begin{array}{c}\text { Mean } \\
\text { (Bos taurus) }\end{array}$ & $\begin{array}{c}\mathrm{N} \\
(\text { Bos indicus })\end{array}$ & $\begin{array}{c}\mathrm{N} \\
(\text { Bos taurus })\end{array}$ & $\mathrm{P}^{*}$ \\
\hline LMY (kg) & 2678 & 2701 & 1491 & 527 & 0.4519 \\
\hline DIM (days) & 296 & 295 & 1491 & 527 & 0.6531 \\
\hline AFC (days) & 1413 & 1401 & 354 & 126 & 0.5958 \\
\hline CI (days) & 515 & 512 & 1123 & 395 & 0.7312 \\
\hline
\end{tabular}

$\mathrm{N}=$ number of valid records; LMY = lactation milk yield; DIM = days in milk; AFC = age at first calving; $\mathrm{CI}=$ calving interval. ${ }^{*}$ The differences between groups were considered to be significant if $\mathrm{P}<0.05$.

The comparison between the two groups showed that the only significant phenotypic difference was for AFC, which was greater for the animals with Bos taurus maternal lineages, when considering the starting period, until 1970. No other significant difference in the performances was observed.

The variance components were estimated with the animal model, providing the estimated proportions amongst the causes of phenotypic variation. The genetic additive, or heritability coefficient, the permanent environment, and random residual proportions are presented in Table 4, regarding LMY, DIM, AFC, and CI.

\begin{tabular}{|c|c|c|c|}
\hline Trait & $h^{2}$ & $c^{2}$ & $e^{2}$ \\
\hline LMY & $0.42(0.003)$ & $0.37(0.002)$ & $0.22(0.005)$ \\
\hline DIM & $0.43(0.065)$ & $0.31(0.055)$ & $0.26(0.017)$ \\
\hline $\mathrm{AFC}$ & $0.20(0.092)$ & - & $0.80(0.092)$ \\
\hline CI & $0.10(0.048)$ & $0.30(0.044)$ & $0.59(0.027)$ \\
\hline
\end{tabular}

$\mathrm{LMY}=$ lactation milk yield; DIM = days in milk; $\mathrm{AFC}=$ age at first calving; $\mathrm{CI}=$ calving interval. The values in parentheses represent the standard errors of the estimates.

The heritability coefficient for lactation milk yield estimated in the present study (0.42) was higher than that observed in many studies. Muir et al. (2004) estimated a heritability coefficient of 0.45 for milk yield in the Holstein breed, while Bolignon et al. (2005) observed a value of 0.30 , and Weber et al. (2005) observed a value of 0.22 , both also for milk yield in Holstein. Roman et al. (2000) observed a heritability coefficient of 0.18 for milk yield in the Jersey breed. In the same paper, these authors presented results from other studies, with estimates varying from 0.25 to 0.38 in the Jersey breed. Cruz et al. (2006) estimated the value 0.13 for the heritability coefficient for milk yield in the Guzerat breed, however, using a production file with a reduced number of records. Cobuci et al. (2000) estimated values from 0.16 to 0.23 and Peixoto et al. (2006) estimated the value of 0.23 , both for the heritability coefficients of milk yield in the Guzerat breed.

Dong et al. (1988), cited by Roman et al. (2000), postulated that heritability coefficient estimates are higher with REML algorithms, when the pedigree is more complete. In 
the present study, the pedigree file was very complete, including animals from various generations before the first production records, and with an excellent genetic connectedness among the recorded animals. This can help explain the superiority of the heritability coefficients for lactation milk yield and days in milk estimated.

With regard to the reproductive traits, the heritability coefficients estimated in this study, 0.20 and 0.10 , for age at first calving and calving interval, respectively, were equivalent to other studies found in the literature (Muir et al., 2004; Duarte and Bastos, 2005).

The analysis showed that all traits studied had significant genetic components explaining the performance variation among the animals.

\section{MtDNA Bos taurus indicus x mtDNA Bos taurus taurus}

The mean genetic breeding values per year of birth, calculated for Bos indicus and Bos taurus maternal lineage animals, were used to draw the scatterplots in Figures 1 to 4, representing the productive and reproductive traits studied. The figures include the representation of the linear regressions of the mean breeding values per year of birth, for each group and for each trait. In addition, there is a vertical line in every figure over the year 1970, with the aim of facilitating the visualization of the two periods considered later in the discussion.

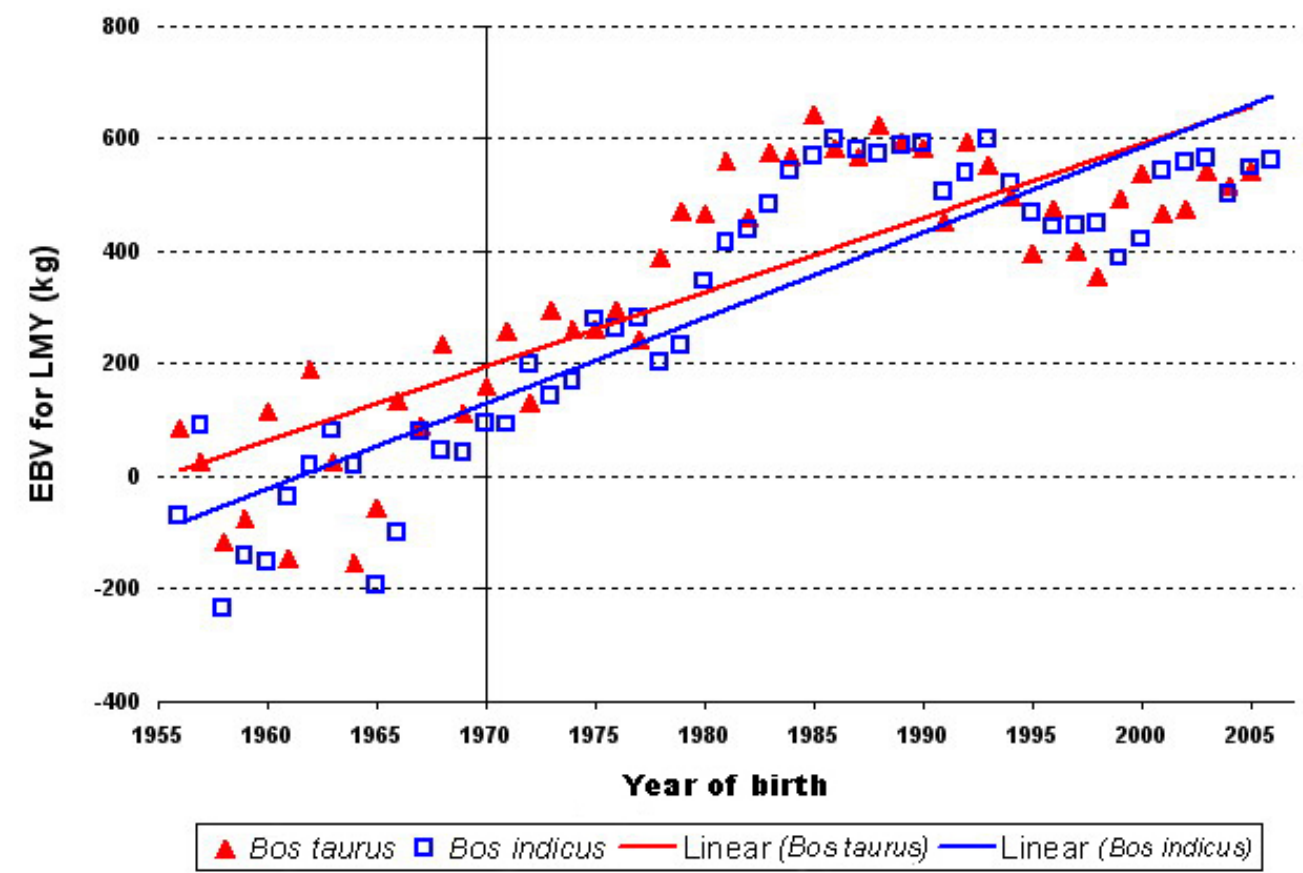

Figure 1. Mean lactation milk yield: genetic breeding values per year of birth, for Bos indicus and Bos taurus maternal lineage animals, from the years 1956 to 2006 . EBV = estimated breeding values; LMY = lactation milk yeld. 


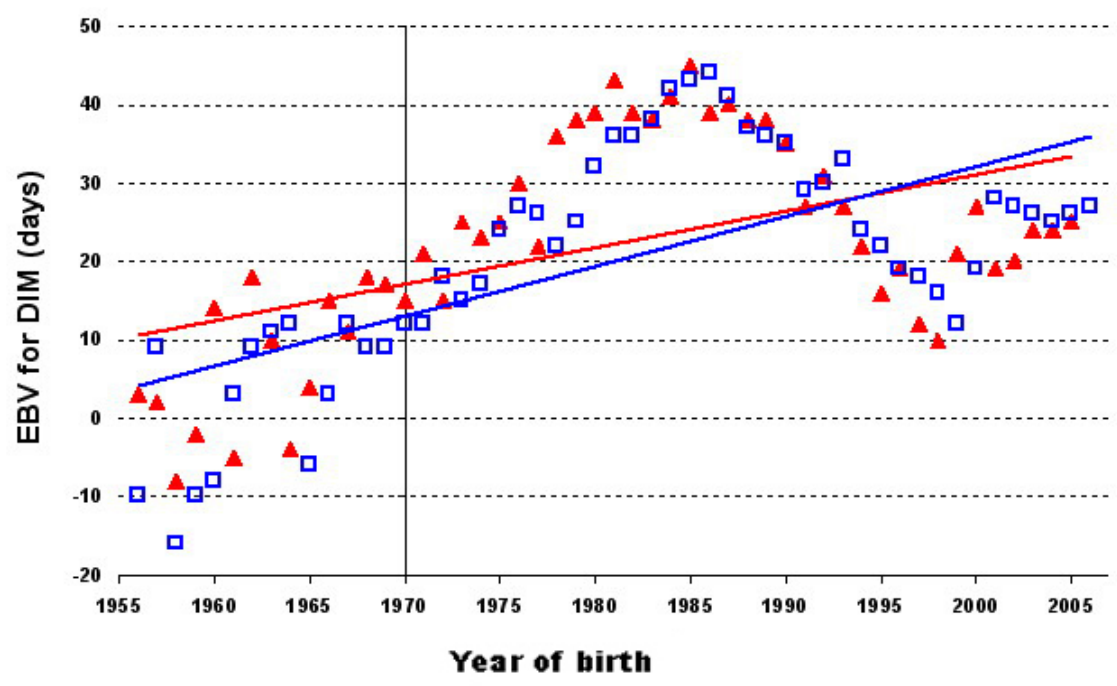

A Bos taurus $\mathbf{\square}$ Bos indicus — Linear (Bostaurus) —-Linear (Bos indicus)

Figure 2. Mean days in milk: genetic breeding values per year of birth, for Bos indicus and Bos taurus maternal lineage animals, from the years 1956 to 2006 . EBV = estimated breeding values; DIM = days in milk.

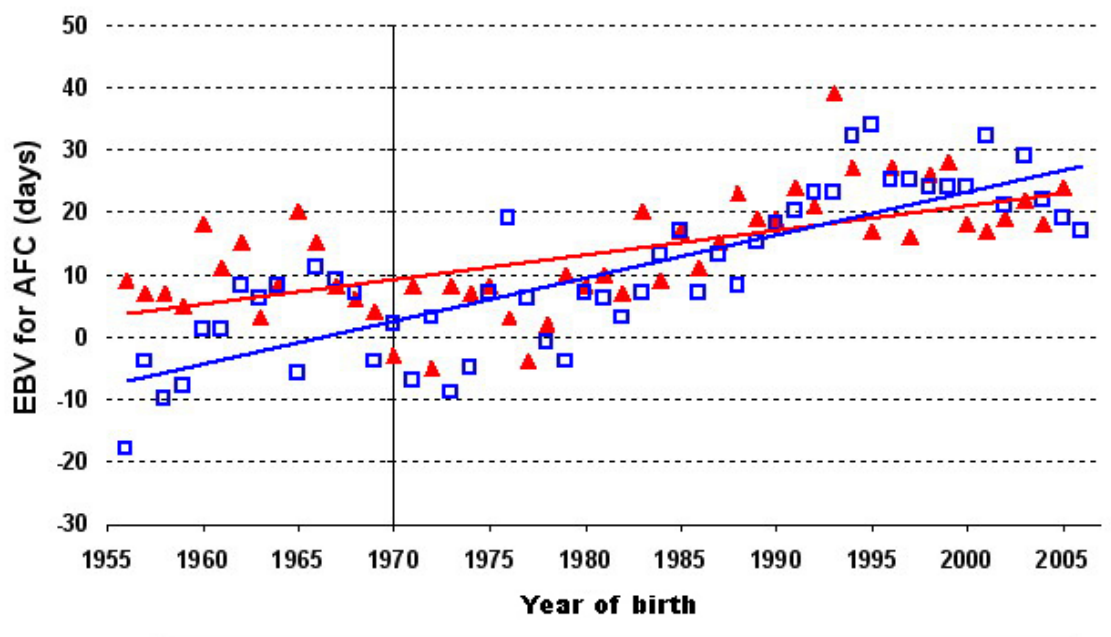

4 Taurinos $\mathbf{a}$ Zebuinos - Linear (taurinos) - Linear (zebuinos)

Figure 3. Age at first calving: genetic breeding values per year of birth, for Bos indicus and Bos taurus maternal lineage animals, from the years 1956 to 2006 . EBV = estimated breeding values; $\mathrm{AFC}=$ age at first calving. 


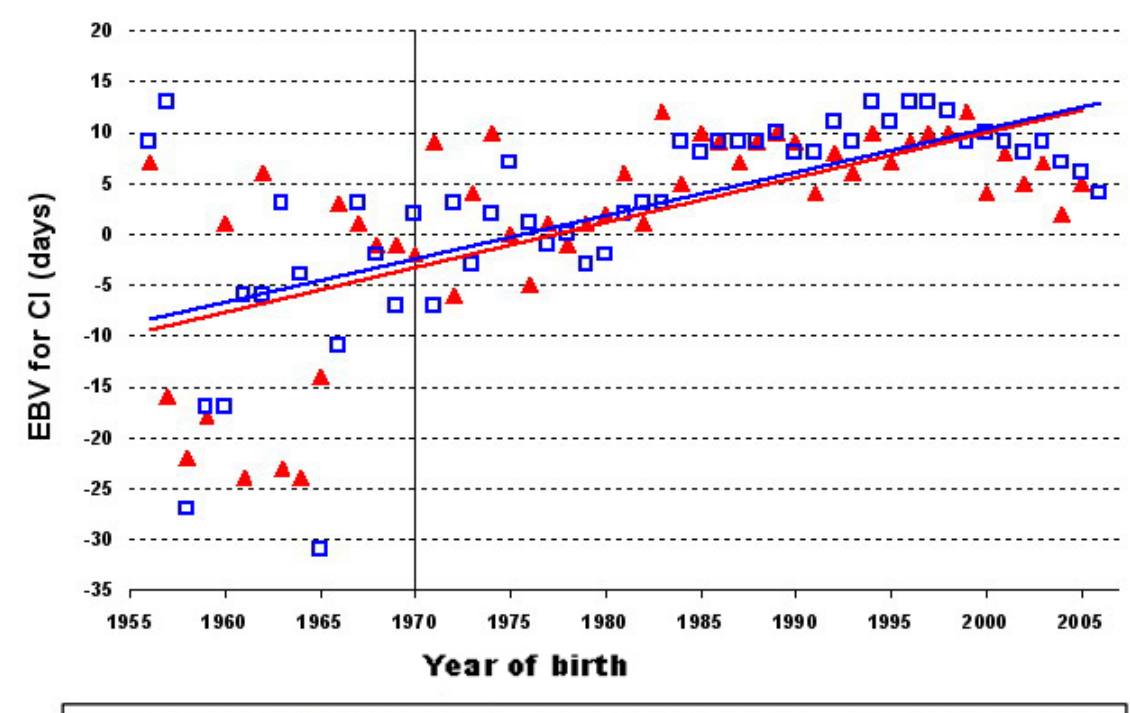

Bos taurus $\mathbf{a}$ Bos indicus —- Linear (Bos taurus) —-Linear (Bos indicus)

Figure 4. Calving interval: genetic breeding values per year of birth, for Bos indicus and Bos taurus maternal lineage animals, from the years 1956 to 2006 . $\mathrm{EBV}=$ estimated breeding values; $\mathrm{CI}=$ calving interval.

Taking into account all animals but not considering mtDNA, it could be observed that LMY and DIM, represented in Figures 1 and 2, respectively, showed a trend of improvement, meaning that the selection had worked in favor of the genes responsible for the increase in production, except for the period from 1985 to 1998, when this improvement was not observed. The observation of the reproductive traits AFC and CI in Figures 3 and 4, respectively, points toward a worsening in the herd's mean breeding values with the time. This in a common unwanted correlated response in herds selected to improve milk yield, as in the study of Melendez and Pinedo (2007). Lucy (2001) explained that this fertility loss is usually associated with the negative energy balance in the post-parturition period, which seems reasonable in the case of the herd studied, where despite the increase in production potential, the herd was not submitted to any improvement in the productive environment conditions, remaining in a low-quality pasture. Thus, the worsening in the mean breeding values on reproductive traits must be considered exclusively for production in low-quality pastures, without supplementation, where the animals were evaluated.

The observation of the two groups, Bos indicus and Bos taurus, separately, allows the perception that the genetic breeding values for LMY, DIM and AFC, in Figures 1, 2 and 3, respectively, differ between the groups especially in the starting period, until 1970, on the left of the figures. This perception was confirmed when the file containing the estimated breeding values was divided into two periods, and the means of the two groups were compared with each other in separate analyses, one for the starting period, until 1970, and other for the more recent period, from 1971 to 2006. The results of the comparisons of the mean estimated breeding values for LMY, DIM, AFC, and CI, involving the animals from the first and second periods are presented in Tables 5 and 6 , respectively. 


\begin{tabular}{|c|c|c|c|c|c|}
\hline Trait & $\begin{array}{l}\text { Mean EBV } \\
\text { (Bos indicus) }\end{array}$ & $\begin{array}{l}\text { Mean EBV } \\
\text { (Bos taurus) }\end{array}$ & $\begin{array}{c}\mathrm{N} \\
\text { (Bos indicus) }\end{array}$ & $\begin{array}{c}\mathrm{N} \\
\text { (Bos taurus) }\end{array}$ & $\mathrm{P}^{*}$ \\
\hline LMY (kg) & -19.38 & 34.77 & 435 & 262 & 0.0109 \\
\hline DIM (days) & 2.81 & 6.15 & 435 & 262 & 0.0162 \\
\hline $\mathrm{AFC}$ (days) & 0.21 & 8.98 & 435 & 262 & 0.0000 \\
\hline CI (days) & -5.42 & -7.70 & 435 & 262 & 0.2215 \\
\hline
\end{tabular}

$\mathrm{N}=$ number of valid records; LMY = lactation milk yield; DIM = days in milk; AFC = age at first calving; $\mathrm{CI}=$ calving interval. *The differences between groups were considered to be significant if $\mathrm{P}<0.05$.

\begin{tabular}{|c|c|c|c|c|c|}
\hline Trait & $\begin{array}{l}\text { Mean EBV } \\
\text { (Bos indicus) }\end{array}$ & $\begin{array}{l}\text { Mean EBV } \\
\text { (Bos taurus) }\end{array}$ & $\begin{array}{c}\mathrm{N} \\
(\text { Bos indicus })\end{array}$ & $\begin{array}{c}\mathrm{N} \\
(\text { Bos taurus })\end{array}$ & $\mathrm{P}^{*}$ \\
\hline LMY (kg) & 455.18 & 460.75 & 1996 & 718 & 0.5966 \\
\hline DIM (days) & 28.72 & 28.67 & 1996 & 718 & 0.9526 \\
\hline AFC (days) & 14.85 & 14.79 & 1996 & 718 & 0.9509 \\
\hline CI (days) & 6.35 & 5.60 & 1996 & 718 & 0.2059 \\
\hline
\end{tabular}

$\mathrm{N}=$ number of valid records; $\mathrm{LMY}=$ lactation milk yield; $\mathrm{DIM}=$ days in milk; $\mathrm{AFC}=$ age at first calving; $\mathrm{CI}=$ calving interval. *The differences between groups were considered to be significant if $\mathrm{P}<0.05$.

When comparing the estimated breeding values of the animals born in the starting period, up to 1970, the Bos taurus maternal lineage group showed better values for lactation milk yield and days in milk. Among these historic animals, the Bos indicus maternal lineage group showed better values for age at first calving, and there was no difference between the two groups regarding calving interval.

When comparing the estimated breeding values of the animals born in the more recent period, from 1971 to 2006, no differences were found between Bos indicus and Bos taurus maternal lineage groups.

\section{CONCLUSIONS}

The segregation of the two groups of maternal lineages, Bos indicus and Bos taurus, existed in the starting period, probably because the maternal Bos taurus contributions to the herd had occurred more recently at that moment. While the animals were mated in and between groups, the differences disappeared with the generations, even if the groups remained identifiable nowadays. Thus, mitochondrial DNA does not seem to have significant effects on lactation milk yield, days in milk, age at first calving, or calving interval.

\section{ACKNOWLEDGMENTS}

Research supported by CNPq, FAPEMIG, PAPE - UNIUBE (Research Support Program from the University of Uberaba), and FZEA/USP. 


\section{REFERENCES}

Anderson S, de Bruijin MHL, Coulson AR, Eperon IC, et al. (1982). Complete sequence of bovine mitochondrial DNA. Conserved features of the mammalian mitochondrial genome. J. Mol. Biol. 156: 683-717.

Boldman KG, Kriese LA, Van Vleck LD, Van Tassell CP, et al. (1995). A manual for use of MTDFREML: a set of programs to obtain estimates of variances and covariances (DRAFT). Department of Agriculture/Agric. Res. Service, Lincoln.

Bolignon AA, Rorato PRN, Ferreira GBB, Weber T, et al. (2005). Herdabilidade e tendência genética para as produções de leite e de gordura em rebanhos da raça Holandesa no estado do Rio Grande do Sul. Rev. Bras. Zootec. 34: 1512-1518.

Cobuci JA, Euclydes RF, Verneque RS, Teodoro RL, et al. (2000). Curva de lactação na raça Guzerá. Rev. Bras. Zootec. 29: 1332-1339.

Cruz GRB, Ribeiro MN, Pimenta Filho EC and Sarmento JLR (2006). Avaliação genética de bovinos Guzerá utilizando-se a produção de leite e de gordura no dia do controle. Rev. Bras. Cienc. Agrar. 1: 103-108.

Duarte MLPR and Bastos JFP (2005). Avaliação das características reprodutivas de um rebanho da raça Guzerá. Cult. Agron. 14: 1-15.

Ferraz JBS (1993). Aplicação de modelos animais na avaliação de parâmetros populacionais das características reprodutivas e produtivas de coelhos das raças Califórnia e Nova Zelândia Branca. Livre-Docência thesis, Faculdade de Zootecnia e Engenharia de Alimentos da USP, Pirassununga.

Giles RE, Blanc H, Cann HM and Wallace DC (1980). Maternal inheritance of human mitochondrial DNA. Proc. Natl. Acad. Sci. U. S. A. 77: 6715-6719.

Hutchison CA III, Newbold JE, Potter SS and Edgell MH (1974). Maternal inheritance of mammalian mitochondrial DNA. Nature 251: 536-538.

Kennedy BW, Schaeffer LR and Sorensen DA (1988). Genetic properties of animal models. J. Dairy Sci. 71: 17-26.

Lucy MC (2001). Reproductive loss in high-producing dairy cattle: where will it end? J. Dairy Sci. 84: 1277-1293.

Madalena FE, Theodoro RL, Lemos AL, Barbosa RT, et al. (1990). Evaluation of strategies for crossbreeding of dairy cattle in Brazil. J. Dairy Sci. 73: 1887-1901.

Martinez ML, Lee AJ and Lin CY (1988). Age and Zebu-Holstein additive and heterotic effects on lactation performance and reproduction in Brazil. J. Dairy Sci. 71: 800-808.

Martinez ML, Verneque RS and Teodoro RL (2000). O zebu na pecuária leiteira nacional. In: Anais do $3^{\circ}$ Simpósio Nacional de Melhoramento Animal, Belo Horizonte, 226-231.

Meirelles FV, Rosa AJM, Lobo RB, Garcia JM, et al. (1999). Is the American Zebu really Bos indicus? Genet. Mol. Biol. 22: 543-546.

Melendez P and Pinedo P (2007). The association between reproductive performance and milk yield in Chilean Holstein cattle. J. Dairy Sci. 90: 184-192.

Mourão GB, Zampar A, Figueiredo LGG, Eller JP, et al. (2005). Efeito do uso dos coeficientes de endogamia na estimação dos valores genéticos de touros da raça Nelore. In: Anais da 42 ${ }^{\mathrm{a}}$ Reunião Anual da Sociedade Brasileira de Zootecnia, Goiânia.

Mourão GB, Figueiredo LGG, Mattos EC, Ferraz JBS, et al. (2006). Linmat - a maternal and cytoplasmatic line identification software. Proceedings of the 8th World Congress on Genetics Applied to Livestock Production, Belo Horizonte, 27-24.

Muir BL, Fatehi J and Schaeffer LR (2004). Genetic relationships between persistency and reproductive performance in first-lactation Canadian holsteins. J. Dairy Sci. 87: 3029-3037.

Peixoto MGCD, Verneque RS, Teodoro RL, Pena VM, et al. (2006). Genetic trend for milk yield in Guzerat herds participating in progeny testing and MOET nucleus schemes. Genet. Mol. Res. 5: 454-465.

Pereira JCC (2004). Melhoramento genético aplicado a produção animal. 4th edn. FEPMVZ Editora, Belo Horizonte.

Powell RL and Norman HD (2006). Major advances in genetic evaluation techniques. J. Dairy Sci. 89: 1337-1348.

Roman RM, Wilcox CJ and Martin FG (2000). Estimates of repeatability and heritability of productive and reproductive traits in a herd of Jersey cattle. Genet. Mol. Biol. 23: 113-119.

Sambrook J and Russel DW (2001). Molecular cloning: a laboratory manual. Cold Spring Harbor Laboratory Press, New York.

Santos R (2005). Guzerá: o gado do Brasil. Agropecuária Tropical, Uberaba.

StatSoft Inc. (2003). Statística: livro base (data analysis software system), version 7.1. Copyright Statsoft, São Caetano do Sul.

Valente J, Durães MC, Martinez ML and Teixeira NM (2001). Melhoramento genético de bovinos de leite. Embrapa Gado de Leite, Brasília.

Weber T, Rorato PRN, Ferreira GBB, Bolignon AA, et al. (2005). Coeficientes de herdabilidade e correlações genéticas para as produções de leite e de gordura, em diferentes níveis de produção, para a raça Holandesa no Estado do Rio Grande do Sul. Rev. Bras. Zootec. 34: 514-519. 